\title{
Pengaruh lama pengeringan terhadap proses Pengolahan kerupuk kulit sapi
}

\author{
F.B. Lilir, C.K.M. Palar, N.N. Lontaan \\ Fakultas Peternakan Universitas Sam Ratulangi Manado 95115
}

\begin{abstract}
ABSTRAK
Penelitian ini bertujuan untuk mengetahui pengaruh lama pengeringan dalam proses pengolahan kulit sapi menjadi kerupuk. Materi utama yang digunakan adalah kulit sapi bagian perut. Penelitian ini dilaksanakan melalui suatu percobaan dengan mengunakan rancangan acak langkap (RAL) terdiri dari 3 perlakuan dan 5 ulangan. Perlakuan yamg diberikan yaitu lama pengeringan: 24 jam, 36 jam, dan 48 jam. Variabel penelitian yang diamati meliputi kadar air, volume pengembangan, warna, aroma, kerenyahan, dan citarasa. Analisis sidik ragam menunjukan pengaruh lama pengeringan terhadap proses pembuatan kerupuk kulit sapi memberikan pengaruh yang berbeda nyata $(\mathrm{P}<0,05)$ terhadap kadar air. Sedangkan pengaruh lama pengeringan terhadap proses pembuatan kerupuk kulit sapi pada volume pengembangan, warna, aroma, kerenyahan, dan citarasa memberikan pengaruh berbeda sangat nyata $(\mathrm{P}<0,01)$. Nilai rata-rata kadar air 2,84 $-2,31 \%$, volume pengembangan $177,22-1801,65 \%$ dan nilai rata-rata kerupuk kulit sapi yg terdiri dari warna 3,87 - 5,05, aroma 3,80 - 4,92, kerenyahan 3,00 - 5,25 dan citarasa 3,25 - 5,05. Kesimpulan dari penelitian ini adalah proses pengolahan kerupuk kulit sapi dengan lama pengeringan 36 jam pada suhu $60^{\circ} \mathrm{C}$ sudah dapat menghasilkan kerupuk kulit sapi yang berkualitas baik dan disukai
\end{abstract}

Kata kunci: Kulit sapi, Lama pengeringan, Kerupuk kulit sapi

\begin{abstract}
EFFECT OF TIME DRYING ON THE PROCESSING OF COW SKIN CRACKERS

This study aims to determine the effect of drying time in the processing of cowhide into crackers. The main material used is cow skin obtained from stomach. This research was conducted through an experiment using a completely randomized design (CRD) consisting of 3 treatments and 5 replications. The research variables observed included moisture content, development volume, color, aroma, crunchy, and taste. Analysis of variance showed that the effect of drying time on the process of making cowhide crackers had a significant effect (P $<0.05)$ on moisture content. While the effect of drying time on the process of making cowhide crackers on the volume of development, color, aroma, crispness, and taste had a very significant effect $(\mathrm{P}<0.01)$. The average value of moisture 2.84-2.31\%, development volume $177.22-1801.65 \%$ and the average value of cowhide crackers consisting of colors $3.87-5.05$, aroma $3.80-4,92$, crunchy $3.00-5.25$ and taste $3.25-5.05$. The conclusion of this study is that the processing of cowhide crackers with a drying time of 36 hours at $60^{\circ} \mathrm{C}$ can produce good quality and preferred cowhide crackers.
\end{abstract}

Keywords: Cowhide, Drying time, Cowhide crackers 


\section{PENDAHULUAN}

Pemanfaatan kulit sapi masih terbatas pada kulit daerah tubuh sapi yang umumnya hanya dipakai dalam industri penyamakan kulit, sedangkan pemanfaatan kulit sapi menjadi kerupuk masih kurang. Salah satu pemanfaatan kulit sapi yaitu dapat diolah menjadi bahan pangan, misalnya dijadikan kerupuk kulit. Kerupuk adalah bahan cemilan bertekstur kering, memiliki rasa yang enak dan renyah sehingga dapat membangkitkan selera makan serta disukai oleh semua lapisan masyarakat. Kerupuk kulit sapi adalah produk makanan ringan yang dibuat dari kulit sapi melalui tahap proses perendaman dalam larutan kapur, pembuangan bulu, perebusan, pengeringan, dan perendaman dengan bumbu untuk kerupuk kulit mentah atau dilanjutkan penggorengan untuk kerupuk kulit siap dikonsumsi (Amertaningtyas, 2011)

Bahan baku dari pembuatan kerupuk kulit adalah kulit sapi yang masih segar. Kerupuk kulit yang berasal dari kulit sapi, kurang mengandung adanya senyawa kolesterol. Hal ini dimungkinkan pada proses pengolahan kulit menjadi kerupuk kulit.

Secara topografis kulit dibagi menjadi 3 bagian yaitu leher, punggung, dan perut. Ketiga bagian kulit ini memiliki struktur lapisan kulit yang berbeda-beda. Pada daerah leher memiliki struktur jaringan yang bersifat longgar dan sangat kuat, daerah punggung memiliki struktur jaringan yang kuat, rapat, merata, serta padat, dan daerah perut merupakan daerah yang memiliki struktur jaringan kulit paling tipis dan longgar. Menurut Said et al., 2011), setiap bangsa ternak mempunyai macam kulit dan ciri khas fungsi yang berbeda-beda sesuai dengan kemampuannya. Rata-rata tebal kulit 1-2 $\mathrm{mm}$ paling tebal $(6 \mathrm{~mm})$ terdapat di telapak tangan dan kaki dan paling tipis $0,5 \mathrm{~mm}$ dengan persentase tergantung jenis ternak, yaitu pada sapi sekitar 6\% - 9\%, domba $12 \%$ - $15 \%$, dan kambing $8 \%$ -
$12 \%$ dari berat tubuh (Said, 2012; Sompie et al., 2012),

Pembuatan kerupuk kulit sapi melalui proses pengeringan. Pengeringan adalah cara untuk mengeluarkan kandungan air melalui penggunaan energi panas. Oleh masyarakat pengeringan sering dilakukan dengan cara tradisional, yakni menggunakan sinar matahari. Proses pengeringan tersebut memberikan hasil yang kurang optimal, membutuhkan waktu yang lama. Selain itu proses penjemuran di area terbuka dapat berdampak pada masalah higienis terhadap produk tersebut. Oleh karena pengeringan merupakan suatu proses utama dalam pembuatan kerupuk, perlu dikaji alternatif yang lain mengenai pengeringan kerupuk kulit sapi. Penggunaan mesin pengering merupakan suatu alternatif dalam proses pengeringan. Namun kurangnya informasi mengenai waktu pengeringan menggunakan mesin, maka perlu dilakukan penelitian mengenai lama pengeringan.

Menurut Jaelani et al. (2014) proses pengeringan yang lakukan tidak mencapai batas, dapat berakibat pada kerusakan kandungan protein pada bahan pangan tersebut. Cahyani dan Hermanto (2019) menyatakan bahwa proses pengeringan dalam pembuatan kerupuk kulit sapi dengan oven menggunakan temperatur $60^{\circ} \mathrm{C}$ diharapkan sudah cukup untuk membunuh sebagian besar mikroorganisme, sedangkan pengeringan pada temperatur lebih tinggi dari $60^{\circ} \mathrm{C}$ dapat menyebabkan denaturasi protein. Namun penelitian tersebut belum memberikan informasi ilmiah mengenai lama waktu yang dibutuhkan dalam proses pengeringan dalam mempertahankan kualitas kerupuk kulit sapi.

Berdasarkan latar belakang, maka dilakukan penelitian dengan tujuan untuk mengetahui lama pengeringan proses pengolahan kerupuk kulit sapi.

\section{MATERI DAN METODE PENELITIAN}




\section{Materi Penelitian}

Materi yang digunakan adalah kulit sapi bagian perut yang diperoleh dari pasar daging Tomohon. Adapun materi penunjang adalah kapur sirih, air, minyak goreng.

Alat yang digunakan dalam penelitian ini adalah alat pengerok bulu, gunting, pisau, oven.

\section{Prosedur Penelitian}

Prosedur penelitian terdiri dari beberapa tahap, yaitu

\section{Penyediaan bahan baku (kulit sapi).}

Memilih dan memisahkan kulit sapi bagian perut dan dipilih bagian kulit yang utuh/tidak robek, tidak cacat, tidak luka/memar, tidak ada bercak hitam pada permukaan kulit.

\section{Pencucian}

Kulit sapi terlebih dahulu dicuci dengan air yang mengalir, tujuannya agar kotoran yang menempel pada kulit sapi tersebut mudah dibersihkan.

\section{Perendaman pada larutan kapur}

Kulit segar yang telah dicuci di rendam dalam larutan kapur (1\% dari berat kulit) seelama 24 jam

\section{Pembuangan bulu}

Pembuangan bulu/pengerokan dilakukan dengan menggunakan pisau atau kater untuk mengerok / memisahkan bulu dari kulit tersebut.

\section{Pencucian setelah perendaman}

Kulit yang sudah dibuang bulunya dicuci kembali dengan air yang mengalir, tujuan dari pencucian adalah untuk menghilangkan kotoran yang masih melekat pada kulit. Pencucian dilakukan berulang-ulang selama tiga kali.

\section{Perebusan}

Selanjutnya dilakukan proses perebusan selama 1 jam hingga kulit mudah untuk di sobek.

\section{Pemotongan bagian kulit}

Pemotongan kulit terdiri dari bagian perut lalu dilakukan pengecilan sampel dengan cara memotong kulit menjadi beberapa potongan dengan ukuran 1 x $3 \mathrm{~cm}$, kemudian masing-masing sampel dimasukan ke dalam wadah yang telah disediakan.

\section{Pengeringan dalam oven}

Kulit yang sudah dipotong dimasukkan ke dalam oven dengan suhu, $60^{\circ} \mathrm{C}$ sesuai dengan lama perlakuan pengeringan 24 jam, 36 jam, 48 jam.

\section{Pengungkepan}

Kulit yang telah dikeringkan dalam oven selanjutnya dilakukan proses pengungkepan dengan menggunakan minyak selama 3 menit

\section{Penggorengan}

Kulit yang telah selasai diungkep langsung digoreng. Minyak yang digunakan pada saat menggoreng agak banyak, tujuannya agar kulit yang digoreng lebih mekar atau mengembang.

\section{Perlakuan Percobaan}

melalui $\begin{gathered}\text { Penelitian ini dilaksanakan } \\ \text { suatu percobaan dengan }\end{gathered}$ mengunakan rancangan acak lengkap (RAL) terdiri dari 3 perlakuan dan 5 ulangan. Perlakuan dan ulangan dalam penelitian ini diatur sebagai berikut:

$\mathrm{P}_{1}=$ pengeringan pada temperatur $60^{\circ} \mathrm{C}$ selama 24 jam.

$\mathrm{P}_{2}=$ pengeringan pada temperatur $60^{\circ} \mathrm{C}$ selama 36 jam.

$\mathrm{P}_{3}=$ pengeringan pada temperatur $60^{\circ} \mathrm{C}$ selama 48 jam.

\section{Variabel penelitian}

Variabel yang diamati adalah Volume pengembangan, kadar air, warna, aroma, kerenyahan, citarasa

\section{Volume pengembangan}

Persentase dari perbandingan antara selisih volume jenis kerupuk mentah dan volume jenis kerupuk goreng dengan volume jenis kerupuk mentah merupakan volume pengembangan kerupuk (Hadiwiyoto, 1983). Rumus volume pengembangan: Persentase Volume Pengembangan $(\%)=\frac{V b-V a}{V a} \mathrm{X} 100 \%$

$\mathrm{Va}=$ Volume kerupuk sebelum digoreng $\mathrm{Vb}=$ Volume kerupuk setelah digoreng

Kadar Air 
Kadar air merupakan banyaknya air yang terkandung dalam bahan baku yang dinyatakan dalam persen. Penentuan kadar air dilakukan dengan pemanasan $105^{\circ} \mathrm{C}$ secara terus menerus sampai sampel bahan beratnya tidak berubah lagi (konstan) (Apriyantono et al., 1989).

Rumus kadar air yaitu:

$\%$ kadar air $=\frac{z-x}{y}$ X $100 \%$

\section{Warna, Aroma, Kerenyahan, Citarasa}

Uji yang dilakukan terhadap warna, aroma, kerenyahan dan citarasa di lakukan dengan cara uji hedonik (Soekarto, 1985). Skala hedonik yang digunakan adalah sebagai berikut :

7 = Sangat suka sekali, $6=$ Sangat suka, 5 = Suka, 4 = Agak suka, $3=$ Agak tidak suka, 2 = Tidak suka, $1=$ Sangat tidak suka

\section{Analisis Data}

Data dianalisis menggunakan analisis varian dan apabila terdapat perbedaan rataan, dilanjutkan dengan uji beda nyata jujur (BNJ).

\section{HASIL DAN PEMBAHASAN}

\section{Kadar air kerupuk kulit sapi}

Data hasil pengamatan untuk pengaruh lama pengeringan terhadap rataan kadar air kerupuk kulit sapi, dapat dilihat pada Tabel 1. Hasil analisis statistic menunjukan bahwa lama pengeringan dalam oven memberikan pengaruh yang berbeda nyata $(\mathrm{P}<0,05)$ terhadap nilai kadar air kerupuk kulit sapi. Hasil uji lanjut beda nyata jujur (BNJ) menunjukkan bahwa perlakuan lama pengeringan 48 jam menghasilkan kadar air yang berbeda nyata $(\mathrm{P}<0,05)$ lebih rendah dari lama pengeringan 24 jam, namun lama pengeringan 36 jam berbeda tidak nyata dengan lama pengeringan 24 jam. Kadar air yang rendah akan meningkatkan kerenyahan pada produk, karena semakin banyak air yang keluar dari bahan maka semakin banyak ruang kosong yang terdapat dalam jaringan sehingga pada saat kerupuk digoreng akan mengembang sampai tingkat tertentu dan menyebabkan kerupuk menjadi lebih renyah (Djunaedi, 2015). Widati dan Mustakim (2007) menyatakan bahwa kadar air yang rendah akan meningkatkan kehalusan pada produk, karena semakin banyak air yang keluar dari bahan maka semakin banyak ruang kosong yang terdapat dalam jaringan. Amertaningtyas et al. (2011) mengemukakan bahwa protein menyerap air dan mengikatnya, sedangkan air yang terikat pada protein tersebut sulit dilepaskan walaupun dengan pemanasan.

\section{Volume pengembangan Kerupuk Kulit Sapi}

Data hasil pengamatan untuk pengaruh lama pengeringan terhadap volume pengembang kerupuk kulit sapi, dapat dilihat pada Tabel 1. Hasil analisis statistik menunjukan bahwa perlakuan lama pengeringan memberikan pengaruh yang berbeda sangat nyata $(\mathrm{P}<0,01)$ terhadap nilai volume pengembangan

Tabel 1. Rataan Pengaruh Perlakuan Terhadap Kadar Air Dan Volume Pengembangan Kerupuk Kulit Sapi

\begin{tabular}{llll}
\hline \multirow{2}{*}{ Variabel } & \multicolumn{3}{c}{ Perlakuan Lama Pengeringan } \\
\cline { 2 - 4 } & P1 (24jam) & P2 (36jam) & P3 (48jam) \\
\hline Kadar air $(\%)$ & $2,84^{\mathrm{a}}$ & $2,56^{\mathrm{ab}}$ & $2,31^{\mathrm{b}}$ \\
Volume pengembangan $(\%)$ & $177,22^{\mathrm{b}}$ & $785,24^{\mathrm{b}}$ & $1801,65^{\mathrm{a}}$ \\
\hline
\end{tabular}

Keterangan: Superskrip berbeda pada baris yang sama menunjukan perbedaan yang nyata $(\mathrm{P}<0,05)$ 
perlakuan lama pengeringan 48 jam menghasilkan volume pengembangan yang berbeda sangat nyata $(\mathrm{P}<0,01)$ lebih tinggi dari lama pengeringan 24 jam, dan berbeda nyata $(\mathrm{P}<0,05)$ lebih tinggi dari lama pengeringan 36 jam, namun lama pengeringan 36 jam berbedatidak nyata $(\mathrm{P}>0,05)$ dengan lama pengeringan 24 jam. Volume pengembangan berhubungan erat dengan kandungan protein kerupuk. Semakin tinggi kandungan protein kerupuk rambak maka semakin rendah daya kembangnya (Wahyuningtyas et al 2014). Kadar kolagen yang ada pada kulit hewan juga dapat mempengaruhi perbedaan volume pengembangan yang dihasilkan. Usia kulit hewan yang digunakan pada kerupuk rambak dari masing-masing produsen dapat mempengaruhi volume pengembangan kerupuk. Hal ini terjadi karena kadar kolagen pada kulit dipengaruhi oleh usia hewan.

Proses penggorengan menyebabkan kerupuk mengalami pemekaran/pengembangan. Terjadinya pengembangan kerupuk disebabkan oleh terbentuknya rongga-rongga udara akibat menguapnya air yang terikat pada struktur kerupuk karena pengaruh suhu penggorengan. Selain itu pada saat perebusan kulit, air akan terikat dalam protein kolagen membentuk gel dengan ikatan yang sangat kuat sehingga pada saat pengeringan sulit diuapkan tetapi dapat dihilangkan pada saat penggorengan karena penggunaan suhu tinggi. Jumlah air yang terserap saat perebusan akan mengubah protein kolagen menjadi gelatin yang akan mempengaruhi tingkat pengembangan dan kerenyahan rambak matang yang dihasilkan (Widati dan Mustakim, 2007).

\section{Warna}

Warna merupakan salah satu parameter yang di ukur dalam penilaian mutu dan tingkat penerimaan panelis atas sebuah produk. Data pada Tabel 2 diketahui bahwa perlakuan yang diberikan berupa lama pengeringan dalam oven menunjukan bahwa tingkat kesukaan panelis terhadap warna kerupuk kulit sapi berkisaran antara 3,87 (agak suka) sampai 5,05 (suka). Nilai rataan skor tertinggi di peroleh pada perlakuan P2 yakni pengeringan pada temperatur $60^{\circ} \mathrm{C}$ selama 36 jam dan terendah pada perlakuan $\mathrm{P} 1$ yakni pengeringan pada temperatur $60^{\circ} \mathrm{C}$ selama 24 jam. Hasil analisis sidik ragam menunjukan bahwa perlakuan lama pengeringan dalam oven memberikan pengaruh yang berbeda sangat nyata $(\mathrm{P}<0,01)$ terhadap warna yang dihasilkan. Berdasarkan hasil uji lanjut dengan uji beda nyata jujur menunjukan bahwa lama pengeringan oven 36 jam berbeda sangat nyata $(\mathrm{P}<0,01)$ lebih tinggi warnanya di bandingkan dengan lama pengeringan oven 48 jam dan berbeda nyata $(\mathrm{P}<0,05)$ lebih tinggi dari lama pengeringan oven 24 jam.

Data hasil uji sensoris warna kerupuk kulit sapi perlakuan P2 yakni pengeringan pada temperatur $60^{\circ} \mathrm{C}$ selama 36 jam lebih di sukai panelis, disebabkan karena warna kerupuk kulit sapi yang di hasilkan lebih putih, juga dipengaruhi oleh lamanya pengeringan dalam oven. Sesuai dengan Standar Nasional Indonesia (SNI) 01-4308-1996, yaitu berwarna normal, juga sesuai dengan pendapat Sompie et al. (2012) bahwa struktur jaringan kulit berpengaruh terhadap sifat-sifat fisik kulit dan pengaruh yang terbesar adalah terdapat pada serabut kolagen.

\section{Aroma}

Data pada Tabel 2, diketahui bahwa perlakuan yang diberikan berupa lama pengeringan dalam oven menghasilkan aroma yang khas dan sangat berpengaruh terhadap aroma kerupuk kulit sapi yang dihasilkan tingkat kesukaan panelis terhadap aroma kerupuk kulit sapi berkisaran antara 3,80 (agak suka) sampai 4,92 (suka). Nilai rataan skor tertinggi diperoleh pada perlakuan P2 yakni pengeringan pada temperatur $60^{\circ} \mathrm{C}$ selama 
Tabel 2. Rataan Pengaruh Perlakuan Terhadap Sifat Sensori kerupuk kulit sapi

\begin{tabular}{llll}
\hline \multirow{2}{*}{ Varibel } & \multicolumn{3}{c}{ Perlakuan Lama Pengeringan } \\
\cline { 2 - 4 } & $\mathrm{P} 1$ & $\mathrm{P} 2$ & $\mathrm{P} 3$ \\
\hline Warna & $3,87^{\mathrm{c}}$ & $5,05^{\mathrm{a}}$ & $4,40^{\mathrm{b}}$ \\
Aroma & $3,80^{\mathrm{c}}$ & $4,92^{\mathrm{a}}$ & $4,60^{\mathrm{b}}$ \\
Kerenyahan & $3,00^{\mathrm{c}}$ & $5,25^{\mathrm{a}}$ & $4,42^{\mathrm{b}}$ \\
Citarasa & $3,25^{\mathrm{c}}$ & $5,05^{\mathrm{a}}$ & $4,40^{\mathrm{b}}$ \\
\hline
\end{tabular}

Keterangan: Superskrip berbeda pada baris yang sama menunjukan perbedaan yang nyata $(\mathrm{P}<0,05)$

36 jam, sedangkan terendah pada perlakuan $\mathrm{P} 1$ yakni pengeringan pada temperatur $60^{\circ} \mathrm{C}$ selama 24 jam.

Berdasarkan nilai aroma kerupuk kulit sapi, panelis lebih menyukai aroma kerupuk kulit sapi dengan perlakuan $\mathrm{P} 1$ yakni pengeringan pada temperatur $60^{\circ} \mathrm{C}$ selama 36 jam dengan skor 4,92 yang termasuk dalam kategori suka. Berdasarkan hasil analisis sidik keragaman menunjukan bahwa perlakuan lama pengeringan dalam oven yang berbeda memberikan pengaruh yang berbeda sangat nyata $(\mathrm{P}<0,01)$ terhadap tingkat kesukaan aroma kerupuk kulit sapi

yang dihasilkan. Hasil uji lanjut menunjukkan bahwa lama pengeringan oven 36 jam berbeda sangat nyata $(\mathrm{P}<0,01)$ lebih baik aromanya di bandingkan dengan lama pengeringan oven 48 jam dan berbeda nyata $(\mathrm{P}<0,05)$ lebih tinggi dari lama pengeringan oven 24 jam. Lama pengeringan oven 48 jam berbeda sangat nyata $(\mathrm{P}<0,01)$ lebih baik aroma dari lama pengeringan oven 24 jam. Berdasarkan hasil uji sensoris, kerupuk kulit sapi memiliki aroma yang khas hal ini dipengaruhi oleh lamanya pengeringan dalam oven. Hal ini berkaitan dengan pernyataan Murtini et al. (2014) bahwa timbulnya aroma makanan disebabkan oleh terbentuknya senyawa yang mudah menguap. Aroma yang dikeluarkan setiap makanan berbeda-beda. Selain itu, cara memasak yang berbeda akan menimbulkan aroma yang berbeda pula (Eriyana dan Syam, 2017). Berdasarkan nilai aroma kerupuk kulit sapi, panelis lebih menyukai aroma kerupuk kulit sapi dengan perlakuan
P1 yakni pengeringan pada temperatur $60^{\circ} \mathrm{C}$ selama 36 jam dengan skor 4,92 yang termasuk dalam kategori suka. Berdasarkan hasil analisis sidik kersgaman menunjukan bahwa perlakuan lama pengeringan dalam oven yang berbeda memberikan pengaruh yang berbeda sangat nyata $(\mathrm{P}<0,01)$ terhadap tingkat kesukaan aroma krupuk kulit sapi yang di hasilkan. Hasil uji lanjut dengan uji beda nyata jujur menunjukan bahwa lama pengeringan oven 36 jam berbeda sangat nyata $(\mathrm{P}<0,01)$ lebih baik aromanya dibandingkan dengan lama pengeringan oven 48 jam dan berbeda nyata $(\mathrm{P}<0,05)$ lebih tinggi dari lama pengeringan oven 24 jam. Lama pengeringan oven 48 jam berbeda sangat nyata $(\mathrm{P}<0,01)$ lebih baik aroma dari lama pengeringan oven 24 jam. Berdasarkan hasil uji sensoris, kerupuk kulit sapi memiliki aroma yang khas hal ini dipengaruhi oleh lamanya pengeringan dalam oven. Hal ini berkaitan dengan pernyataan (Murtini et al., 2014) bahwa timbulnya aroma makanan disebabkan oleh terbentuknya senyawa yang mudah menguap. Aroma yang dikeluarkan setiap makanan berbeda-beda. Selain itu, cara memasak yang berbeda akan menimbulkan aroma yang berbeda pula (Eriyana et al., 2017).

\section{Kerenyahan}

Data pada Tabel 3, menunjukan bahwa perlakuan yang diberikan berupa lama pengeringan dalam oven berpengaruh terhadap kerenyahan kerupuk kulit sapi yang dihasilkan. Hasil yang di peroleh menunjukan bahwa tingkat kesukaan 
panelis terhadap kerenyahaan kerupuk kulit sapi dengan perlakuan yang berbeda, berkisaran antara 3,00 (tidak suka) sampai 5,25 (agak suka). Nilai rataan skor tertinggi terdapat pada perlakuan $\mathrm{P} 2$ yakni pengeringan pada temperatur $60^{\circ} \mathrm{C}$ selama 36 jam. Sedangkan terendah pada perlakuan $\mathrm{P} 1$ pengeringan pada temperatur $60^{\circ} \mathrm{C}$ selama 24 jam.

Berdasarkan hasil analisis sidik ragam menunjukan bahwa perlakuan lama pengeringan dalam oven memberikan pengaruh yang berbeda sangat nyata $(\mathrm{P}<0,01)$ terhadap kerenyahan kerupuk kulit sapi yang di hasilkan. Setelah dilanjutkan dengan uji beda nyata jujur menunjukan bahwa lama pengeringan oven 36 jam berbeda sangat nyata $(p<0,01)$ lebih tinggi kerenyahan di bandingkan dengan lama pengeringan oven 48 jam dan berbeda nyata $(\mathrm{P}<0,05)$ lebih tinggi kerenyahan dari lama pengeringan oven 24 jam. Lama pengeringan oven 48 jam berbeda sangat nyata $(\mathrm{P}<0,01)$ lebih tinggi kerenyahan dari lama pengeringan oven 24 jam.

Berdasarkan hasil uji sensori, pelakuan pada kerupuk kulit sapi menghasilkan kerenyahan yang di sukai oleh panelis hal ini mungkin dikarenakan perlakuan lama pengeringan dalam oven berpengaruh terhadap kerenyahan kerupuk kulit sapi yang dihasilkan, kerenyahan merupakan sifat penting dalam penerimaan produk hasil penggorengan seperti kerupuk. Tekstur kering hasil penggorengan tergantung pada kemudahan terputusnya partikel penyusunnya pada saat pengunyahan dan tergantung pula pada ukuran dan kekukuhan granulagranula pati yang sudah mengembang (Irmayanti et al., 2017). Adanya peningkatan tingkat kerenyahan ini diduga karena adanya kapur pada proses pengapuran, maka proses gelatinisasi terjadi lebih sempurna sehingga akan menghasilkan struktur yang lebih porous setelah digoreng. Sedangkan pada perebusan dengan air panas, molekul air yang terperangkap pada jaringan semakin banyak, menyebabkan air tidak semuanya dapat teruapkan pada waktu penggorengan. Semakin banyak air yang tidak teruapkan semakin mengurangi keporousan kerupuk sehingga kerenyahan menurun. Tekstur produk pangan dipengaruhi oleh protein yang mengalami denaturasi atau koagulasi (Muchtadi \& Sugiyono, 2014).

\section{Citarasa}

Citarasa merupakan faktor terpenting terhadap akseptabilitas selain warna, aroma, kerenyahan. Berdasarkan Tabel 2, diketahui bahwa perlakuan yang di berikan berupa lama pengeringan dalam oven jam yang berbeda menunjukan bahwa tingkat kesukaan panelis terhadap citarasa kerupuk kulit sapi dengan perlakuan yang berbeda berkisaran antara 3,25 (agak suka) sampai 5,05 (suka).

Berdasarkan hasil analis sidik ragam menunjukan bahwa perlakuan lama pegeringan dalam oven memberikan pengaruh yang berbeda sangat nyata $(\mathrm{P}<0,01)$ terhadap citarasa kerupuk kulit sapi. Berdasarkan hasil uji lanjut dengan hasil uji beda nyata jujur menunjukan bahwa lama pengeringan oven 36 jam berbeda sangat nyata $(\mathrm{P}<0,01)$ lebih tinggi citarasa dibandingkan dengan lama pengeringan oven 48 jam dan berbeda nyata $(\mathrm{P}<0,05)$ lebih tinggi citarasa dari lama pengeringan oven 24 jam. Lama pengeringan oven 48 jam berbeda sangat nyata $(\mathrm{P}<0,01)$ lebih tinggi citarasa dari lama pengeringan oven $24 \mathrm{jam}$. Data-data tersebut menunjukan bahwa panelis lebih menyukai kerupuk kulit sapi dengan perlakuan $\mathrm{P} 2$ pengeringan pada temperatur $60^{\circ} \mathrm{C}$ selama 36 jam hal ini di pengaruhi oleh perlakuan yang di berikan. Hal ini sesuai dengan pernyataan dari (Ismed, 2016) menyatakan bahwa makanan yang diproses dengan penggorengan menjadi lebih gurih. Hal ini juga didukung oleh Ratnaningsih (2007); Iskandar et al. (2018) menyatakan bahwa minyak berperan dalam memberikan cita rasa pada 
bahan pangan yang digoreng. Minyak yang diserap akan merenyahkan makanan.

\section{KESIMPULAN}

Berdasarkan hasil analisis dan pembahasan dapat disimpulkan bahwa proses pengolahan kerupuk kulit sapi dengan lama pengeringan 36 jam pada suhu $60^{\circ} \mathrm{C}$ sudah dapat menghasilkan kerupuk kulit sapi yang berkualitas baik dan disukai.

\section{DAFTAR PUSTAKA}

Amertaningtyas, D. 2011. Pengolahan kerupuk "Rambak" kulit di Indonesia. Jurnal Ilmu-ilmu Peternakan 21 (3): 18 - 29

Amertaningtyas. D., Masdiana Ch. Padaga ,Manik E , S, Abdul M, dan Khothibul U, Al-Awwaly. 2011. kualitas kerupuk rambak kulit kelinci (kadar air dan daya kembang) dengan menggunakan teknik buang bulu yang berbeda, Jurnal Ilmu dan Teknologi Hasil Ternak, Maret 2011, Hal 1-6 Vol. 6, No. 1

Apriyantono, A., D. Fardiaz, N. L. Puspitasari, Sedernawati. Dan S. Budiyanto.1989 Petunjuk Laboratorium Analisa Pangan. PAU, IPB. Bogor

Cahyani, S. dan T. Hermanto. 2019. Pengaruh lama dan suhu pengeringan terhadap karakteristik organoleptik, aktifitas antioksidan dan kandungan kimia tepung kulit pisang ambon (Musa Acuminata Colla). J. Sains dan Teknologi Pangan Vol. 4, No.1, P. 2003-2016, Th 2019

Djunaedi, E. 2015. Pemanfaatan Limbah Kulit Pisang Sebagai Sumber Pangan Alternatif dalam Pembuatan Cookies. Skripsi. Program Studi Kimia Universitas Pakuan. Bogor
Eriyana, E. dan H. Syam. 2017. Mutu dodol pisang berdasarkan subtitusi berbagai jenis pisang (Musa Paradisiaca). Jurnal Pendidikan Teknologi Pertanian 3(1): 34-41

Hadiwiyoto. 1983. Hasil - Hasil Olahan Susu, Ikan, Daging dan Telur. Liberty, Yogyakarta.

Iskandar, H., P. Patang, H. Kadirman. 2018. Penggolahan talas (Colocasia esculenta L., schott) menjadi keripik menggunakan alat vacum frying demgan variasi waktu, Jurnal Pendidikan Teknologi Pertanian 4(1): 29-42

Ismed, I. 2016. Analisis proksimat keripik wortel (Daucus carota, 1.) pada suhu dan lama penggorengan yang berbeda menggunakan mesin vacuum frying. Jurnal Teknologi Pertanian Andalas 20(2): 25-32

Irmayanti, I., H. Syam dan J. Jamaluddin. 2017. Perubahan Tekstur Kerupuk Berpati Akibat Suhu Dan Lama Penyangraian. Jurnal Pendidikan Teknologi Pertanian. Universitas Negeri Makassar. Vol. 3: 165-174

Jaelani, A., A. Gunawan dan I. Asriani. 2014. Pengaruh lama penyimpanan silase daun kelapa sawit terhadap kadar protein dan serat kasar. Ziraa'ah Majalah Ilmiah Pertanian 39(1): 8-16.

Muchtadi, T. R. dan Sugiyono. 2014. Prinsip dan Proses Teknologi Pangan. Alfabeta, Bandung, 320 hlm

Murtini, J. T., R. Riyanto, N. Priyanto dan I. Hermana. 2014. Pembentukan formaldehid alami pada beberapa jenis ikan laut selama penyimpanan dalam es curai. JPB Perikanan 9(2): 143-151.

Ratnaningsih, B. Raharjo dan S. Suhargo. 2007. Kajian penguapan air dan penyerapan minyak pada penggorengan ubi jalar (Ipomoea batatas $L$.) dengan metode deep fat frying. Agritech 27(1): 
Said, M. I . 2012. Bahan Ajar Ilmu dan Teknologi Pengolahan Kulit (339 I 123). Fakultas Peternakan Universitas Hasanuddin, Makassar. Said, M. I., S. Triatmojo, Y. Erwanto dan A. Fudholi. 2011. Karakteristik gelatin kulit kambing yang di produksi melalui proses asam basa. Agritech 31(3): 190 - 200

Sompie, M, S. Triatmojo, A. Pertiwiningrum dan Y. Pranoto. 2012. Pengaruh umur potong dan konsentrasi larutan asam asetat terhadap sifat fisik dan kimia gelatin kulit babi. Sains Peternakan 10(1): 15-22

Sompie, M., S. Triatmojo, A. Pertiwiningrum dan Y. Pratono. 2012. The effect of animal age and acetic concertration on pigskin gelatin characteristic. J. Indonesia Tropical Animal Agriculture 37(3): 176-182

Soekarto, S.T. 1985. Penilaian Organoleptik untuk Industri Pangan dan Hasil Pertanian. Bhratara Karya Aksara. Jakarta.

Wahyuningtyas, N., B. Basito, W. Atmaka. 2014. Kajian karakteristik fisikokimia dan sensoris kerupuk berbahan baku tepung terigu, tepung tapioka dan tepung pisang kepok kuning. Jurnal Teknosains Pangan 3(2):

Widati, A.S. dan S.I. Mustakim. 2007. Pengaruh lama pengapuran terhadap kadar air, kadar protein, kadar kalsium, daya kembang, dan mutu organoleptik kerupuk rambak kulit sapi. Jurnal Ilmu dan Teknologi Hasil Ternak 2(1): 4756. 